\title{
THE ASSOCIATION BETWEEN ATTITUDE AND ADHERENCE TO TAKE ANTI-TUBERCULOSIS DRUGS IN TUBERCULOSIS PATIENTS IN KUPANG HEALTH CENTER, EAST NUSA TENGGARA
}

\author{
Bringiwatty Batbual'), Wanti'), Kusmiyati'), Jefrin Sambara'), Irfan'1), \\ Florentianus Tat'), Petrus Belarminus'), Yohan Charles ${ }^{2)}$ \\ ${ }^{1)}$ Health Polytechnics Ministry of Health, Kupang, East Nusa Tenggara \\ ${ }^{2)}$ Kupang District Health Office, East Nusa Tenggara
}

\begin{abstract}
Background: Based on data from Perdaki NTT (2021), the absolute number of TB case finding in 2018-2020 in NTT in 2018 was 7,632 cases. In 2019 there were 7,575 cases and in 2020 there were 5,126 cases. This decrease in case finding could be due to the decreased number of tracing due to the impact of COVID-19. This study aimed to determine the relationship between the attitudes of TB patients and adherence to taking antituberculosis drugs.

Subjects and Method: This was a cross-sectional study conducted at Tarus, Naibonat, and Camplong Health Centers, Kupang, East Nusa Tenggara, Indonesia, from July to October 2021. A number of $40 \mathrm{~TB}$ patients was selected purposively. The dependent variable was adherence to take anti-TB drugs. The independent variable was attitude. The data were collected by medical record and questionnaire. The data were analyzed by Pearson correlation.

Results: Most of TB patients had positive attitude (92.5\%) and adherent to take antiTB drugs (95.0\%). Positive attitude was associated with improved adherence to take antiTB drugs $(\mathrm{r}=0.56 ; \mathrm{p}<0.001)$.

Conclusion: Positive attitude is associated with improved adherence to take anti-TB drugs.
\end{abstract}

Keywords: tuberculosis, attitude, compliance.

\section{Correspondence:}

Bringiwatty Batbual, Health Polytechnics, Ministry of Health, Kupang, East Nusa Tenggara, Jl Piet A. Tallo, Liliba, Kupang, East Nusa Tenggara. Email: wattybatbual155@gmail.com Mobile: +6282147293150. 